\title{
Lawsonia intracellularis and Porcine Circovirus type-2 infection in Estonia
}

\author{
T. Järveots ${ }^{1}$, T. Saar ${ }^{1}$, D. Põdersoo ${ }^{1}$, S. Rüütel-Boudinot ${ }^{2}$, S. Sütt' ${ }^{1}$, \\ L. Tummeleht ${ }^{1}$, T. Suuroja ${ }^{1}$, R. Lindjärv ${ }^{1}$
}

${ }^{1}$ Estonian University of Life Science, Department of Basic Veterinary Sciences and Population Medicine ${ }^{2}$ Tallinn University of Technology, Department of Gene Technology, Immunology unit, Estonia

\begin{abstract}
The present study describes the reasons of post-weaning distress in Estonian pig herds. Here we examined the natural cases of Lawsonia intracellularis and porcine circovirus 2 (PCV2) infection and co-infections.

The presence of $L$. intracellularis in swine herds were tested by PCR and by histopathological methods, whereas PCV2 was detected by real-time-PCR and immunohistochemical stainings. Seven of the 11 investigated herds with signs of post-weaning wasting were infected with $L$. intracellularis and all 11 herds with PCV2.

From the analysed samples $22.2 \%$ were infected with $L$. intracellularis and $25 \%$ with PCV2. The results of microbiological studies suggested that the piglets suffered from enteritis and pneumonia. Escherichia coli and Pasteurella multocida often aggravated the process of illness. The frequency of $L$. intracellularis was high in pigs 7-12 weeks old (18.5-42.7\%) and PCV2 infection was too high in pigs 7-12 weeks old (24.8-32.7\%). E. coli was often a co-factor with L. intracellularis and PCV2.

The primary reasons of post weaning wasting were PCV2 and E. coli, later aggravated by $L$. intracellularis and other pathogens. Our results indicated that different pathogens have an important role in developing post-weaning wasting.

Proliferative intestinal inflammation caused by L. intracellularis is mainly characterised by its localization and morphological findings. The main gross lesions were the enlargement of mesenteric lymph nodes and thickening of the wall of ileum. In post-weaning multi-systemic wasting syndrome there are characteristic histological lesions in lymphoid tissues. They consist of a variable degree of lymphocyte depletion, together with histiocytic and/or multinucleate giant cell infiltration. This basic lymphoid lesions is observable in almost all tissues of a single severely affected animal, including lymph nodes, Peyer's patches and spleen. Sporadically, multifocal coagulative necrosis may be observed.
\end{abstract}

Key words: Lawsonia intracellularis, Porcine Circovirus type-2 


\section{Introduction}

Lawsonia intracellularis and porcine circovirus type 2 are important pathogens in modern pig breeding and rearing. Many studies are available on the prevalence of these pathogens in different countries, a limited amount of data are available on the prevalence of L. intracellularis and PCV2 in Estonian pig herds.

Porcine proliferative enteropathy (PPE) is caused by the obligate intracellular bacteria Lawsonia intracellularis. PPE in pigs occurs as several different syndromes and all forms of PPE share unique histological features, including the proliferation of the immature epithelial cells of the intestinal crypts, causing a thickening of the mucosa of the small and sometimes large intestine (Lomax et al. 1982, McOrist et al. 1995, 2006, Joens et al. 1997, MacIntyre et al. 2003, Yeh et al. 2006). PPE also known as ileitis, is a common infectious disease affecting weaned pigs of various ages, causing diarrhea, stunted growth and occasionally sudden death (Lawson et al. 2000). This disease appears to be widespread in swine populations all over the world (Zhang, et al. 2000, Stege et al. 2001, Moreno et al. 2002, Jacobson et al. 2003, Plawinska et al. 2004, Suh and Song. 2006). It has been shown that $L$. intracellularis multiplies in epithelial cells of the gut of affected pigs causing microscopic changes, which can only be detected histopathologically.

Among pigs, there are two types of circoviruses described: PCV1 that is non-pathogenic and PCV2 that has been associated syndromes as an infectious agent of post-weaning multi-systemic wasting syndrome (PMWS), and other symptoms as unthriftiness, pallor, icterus, respiratory distress and diarrhea. In addition, the more severe course of disease is characterised by a remarkably high number of runted pigs (McOrist et al. 1995). PCV2 is widely prevalent in pigs with respiratory disorders and should be considered a major respiratory pathogen (Kim et al. 2003).

PCV2 infection is characterized microscopically by depletion and histocytic replacement of follicles in lymphoid tissues; giant cells and cytoplasmatic inclusions in macrophages are also characteristic of PCV2 associated diseases. The prevalence of PCV2 and co-infection with other viral and bacterial pathogens in pigs with respiratory disorders and enteritis has not been determined but could be of significant importance in epidemiological survey programs. This syndrome is the major disease affecting commercial herds of swine worldwide. In Europe PCV2 has been present in Northern Germany since 1962 (Jacobsen et al. 2009). In Estonia PMWS was diagnosed in 2006 (Timmusk et al. 2008).

The purpose of this study was to describe the frequency and microscopic lesions caused by $L$. intracellularis and the prevalence of PCV2 infections using the methods of histopathology and molecular biology.

\section{Material and Methods}

\section{Sample collection}

Pathological materials for detection of $L$. intracellularis and porcine circovirus- 2 and for bacteriological investigations were collected from 11 pig herds in Estonia.

All selected herds had clinical symptoms of porcine proliferative enteropathy and/or post-weaning multisystemic wasting syndrome. The age of affected pigs was 4-20 weeks and a sample size was 40-60 per herd. The size of herds varied between 100 and 9950 sows. Weaning time was between 27-30 days. Morbidity ranged from $20 \%$ to $60 \%$ with an average mortality of $10 \%$ to $41 \%$ (included runted). The sampled piglets were selected amongst those showing possible signs of the disease (poor growth, diarrhea).

A total of 510 samples: 461 fecal samples and 49 intestinal mucosa (ileum) for detection of genetic material of L. intracellularis. Fecal samples for the detection of L. intracellularis were collected from the rectum. The samples were transported to the laboratory within $10 \mathrm{~h}$ and kept in a freezer $\left(-20^{\circ} \mathrm{C}\right)$ for further examinations.

124 pathological materials (mesenteric and inguinal lymph nodes, lungs, spleen and intestine) were collected for detection of PCV2 using histopathological, immunohistochemistry and molecular biology methods and kept in a freezer $\left(-80^{\circ} \mathrm{C}\right)$ for further examinations.

\section{Bacteriology}

Bacteriological investigations were done using standard bacteriological procedures (Quinn et al. 1994). MacConkey and blood agar were used for cultivating of samples. For preparing of blood agar to Columbia agar base $10 \%(\mathrm{v} / \mathrm{v})$ bovine anticoagulated blood in $10 \mathrm{ml}$ Vacutainer K3E (Becton Dickinson) tubes were added. Biochemical characterization and identification of isolated bacterial strains were performed with the „Crystal” indication system (Becton Dickinson, USA). 


\section{Bacterial DNA extraction and PCR analysis for detection of $L$. intracellularis}

Bacterial DNA was purified from the pathological materials by using the QIAamp ${ }^{\circledR}$ DNA Mini Kit (QIAGEN) according to the manufacturer's instructions. DNA was amplified by PCR using commercial kit (ADIAVET ${ }^{\circledR}$ LAW, France) and the conditions for the reaction were as described in the manufacturer's instructions.

\section{Viral DNA extraction and PCR analysis for detection of PCV2}

Due to the broad variation in sample collection period, the samples for PCV2 analysis from the seven farms were analysed in Estonian Veterinary and Food Laboratory (VFL) and the samples from three farms in the Department of Biomedical Sciences and Veterinary Public Health at the Swedish University of Agricultural Sciences (SLU). In VFL total viral DNA from tissue samples (liver, spleen and/or mesenteric and bronchial lymph nodes) was extracted by using Invisorb RTP ${ }^{\circledR}$ DNA/RNA Virus Mini Kit using extraction procedure according to the manufacturers instructions (Invitek). Primers and reaction conditions used in the PCR are described in Ladekjćr-Mikkelsen et al. (2002). The primer pair PCV2ORF1 5'-GATGATCTACTGAGACTGTGTGA-3',

FAM-PCV2ORF1 5'-6-FAM-AGAGCTTCTA CAGCTGGGACA-3' and PCV2 specific probe 5'-TCAGACCCCGTTGGAATGGTACTCCTC-Cy5 -3 ' are amplifying the sequence conserved between PCV1 and PCV2.

In SLU viral DNA from the mesenterial lymph node tissue samples was extracted using QIAamp DNA Mini kit or DNA Robot Mag kit (QIAGEN) and used as a template for further PCR amplification. The full length ORF2 sequence (1134 bp) was amplified using the following praimer pair: F: 5' TGCCGCTGCCGAAGTGCGCTG 3' and R: 5' ATTTTGGAAGAATGCTACAGA 3' as published in Timmusk et al. (2008).

\section{Immunohistochemistry}

124 tissue samples (mesenteric and inguinal lymph nodes, lungs, spleen, bowel) were collected for immunohistochemical stainings. Tissue samples were fixed in $10 \%$ neutral buffered formalin and in a fixator of Rossmann. Histological specimens were stained with haematoxylin and eosin and by Warthin-Starry silver staining.
Immunohistochemistry (IHC) for PCV2 was performed in formalin-fixed and paraffin-embedded tissue. Tissue sections were deparaffinised with xylene and rehydrated through graded alcohols.

Endogenous peroxidase activity was blocked by incubation with hydrogen peroxide $0,6 \%$ in TBS for 20 $\mathrm{min}$. Tissue sections were rinsed three times in $0,15 \mathrm{M}$ Tris-buffered saline (TBS), $\mathrm{pH} \mathrm{7,6}$ and treated with Protease XIV (Sigma) for $15 \mathrm{~min}$ at $37^{\circ} \mathrm{C}$. Then, tissue sections were rinsed again in TBS and incubated with universal blocking regent (Power Block, BioGenex Laboratories) diluted 1:100 for 10 minutes. PCV2 monoclonal antibody (provided by Danish Institute for Food and Veterinary Research) was used at the dilution of 1:300 in TBS and incubated overnight at room temperature. After 3 washes with TBS, sections were incubated with EnVision $+{ }^{\mathrm{TM}}$ System (DakoCytomation) for 30. The specific colour reaction was developed for 10 min with 3-amino-9-ethyl carbazole (AEC, Kem-En-Tec Diagnostics, USA). Finally sections were counterstained with Mayer's haematoxylin and mounted in glycerol (DakoCytomation).

\section{Results}

All 11 herds were infected with PCV2 and seven of the investigated herds with $L$. intracellularis (Table 1). $113(22.2 \%)$ out of 510 samples were positive to L. intracellularis and $31(25 \%)$ samples out of 124 samples were positive to PCV2.

The results of microbiological analysis suggested that the piglets suffered from enteritis and pneumonia. The most common bacteria associated with pneumonia was Pasteurella multocida. In one herd Actinobacillus pleuropneumoniae (APP biotype I hly $\beta^{+}$) was isolated. In five herds enterohemorrhagic E. coli (EHEC) was isolated in the cases of acute and subacute enteritis in weaned piglets. Two herds were infected simultaneously with E. coli and PCV2. In three herds $L$. intracellularis and PCV2 were diagnosed together with $P$. multocida and $E$. coli. Only two of the 11 herds were infected solely with PCV2.

One herd was affected by five pathogens (L. intracellularis, PCV2, APP, P. multocida and E. coli). The average mortality of suckling piglets was $0.5-17 \%$ and in post-weaning period $1-18 \%$ (Table 1).

The pigs under examination were divided into 7 groups, according to their age: 0-4, 5-6, 7-8, 9-10, 11-12, 13-16, 17-20 weeks old (Fig. 1). The shedding of PCV2 together with $L$. intracellularis began in 5-6 weeks old group, the percentage of PCV2 increased to $9.5 \%$ but $L$. intracellularis was found only $3.7 \%$. The 
Table 1. Diagnosis of L. intracellularis, PCV2 and other pathogens in Estonian pig herds.

\begin{tabular}{|c|c|c|c|c|c|c|c|}
\hline \multirow{2}{*}{ Herd } & \multirow{2}{*}{$\begin{array}{l}\text { Mortality } \\
\text { of sucklings } \\
(\%)\end{array}$} & \multirow{2}{*}{$\begin{array}{l}\text { Post-weaning } \\
\text { mortality } \\
(\%)\end{array}$} & \multicolumn{2}{|c|}{ L. intracellularis } & \multicolumn{2}{|c|}{ PCV2 } & \multirow{2}{*}{ Other pathogens } \\
\hline & & & samples & posit $(\%)$ & samples & posit $(\%)$ & \\
\hline 1 & 7 & 3 & 58 & - & 13 & $3(23.1)$ & E. coli \\
\hline 2 & 15 & 1 & 45 & $19(42.2)$ & 12 & $4(33.3)$ & E. coli, P. multocida \\
\hline 3 & 1 & 1 & 31 & $10(32.2)$ & 7 & $1(14.2)$ & E. coli, P. multocida \\
\hline 4 & 13 & 6.7 & 52 & $17(32.6)$ & 15 & $4(26.6)$ & \\
\hline 5 & 17 & 5 & 60 & $23(38.3)$ & 10 & $2(20)$ & \\
\hline 6 & 9.5 & 7 & 47 & - & 9 & $5(55.5)$ & \\
\hline 7 & 0.6 & 6.5 & 49 & $18(36.7)$ & 14 & $5(35.7)$ & E. coli, P. multocida, APP \\
\hline 8 & 0.5 & 2.3 & 35 & $8(22.8)$ & 12 & $6(50)$ & \\
\hline 9 & 12 & 18 & 56 & - & 8 & $2(25)$ & E. coli \\
\hline 10 & 2 & 1 & 48 & $18(37.5)$ & 13 & $1(7.7)$ & \\
\hline 11 & 10 & 5 & 29 & - & 11 & $2(18.2)$ & \\
\hline
\end{tabular}

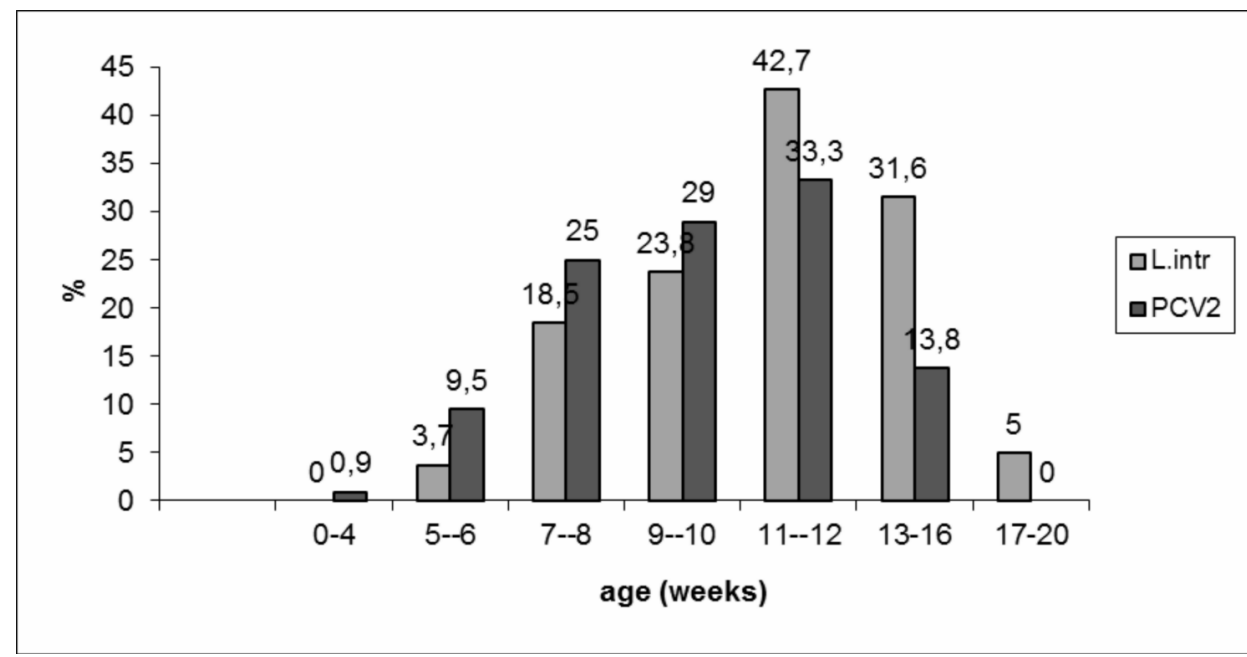

Fig. 1. Frequency of Lawsonia intracellularis and PCV2 detection (\%) from pigs according to the age (weeks).

percentage of L. intracellularis and PCV2 increased continuously, in the 9-10 weeks old group it was $23.8 \%$ and $29 \%$, but the peak of $L$. intracellularis increased considerably in pigs aged 11-12 weeks $(42.7 \%)$. In the same group the percentage of PCV2 increased up to $33.3 \%$. Among 13-16 weeks old pigs the percentage of PCV2 decreased (13.8\%), but the percentage of $L$. intracellularis was relative high $(31.6 \%)$. Our investigations suggested that 7-10 weeks old pigs were infected more often with PCV2 and in 11 weeks old pigs the agent of PPE prevailed.

The main gross lesions were enlargement of mesenteric lymph nodes and thickening of the wall of the ileum. The affected mucosa was thrown into deep longitudinal and transverse folds (Fig. 2).

There was hyperplasia of lymphoid tissue and, in many cases, pseudomembranous inflammation. It is suggested that $L$. intracellularis is preferably localised in enterocytes of gut crypts of jejunum, cecum and upper third of the proximal colon. The main histological findings were in the ileal crypts with epithelial hyperplasia, decreased number of goblet cells, histiocytic and neutrophilic infiltrates in the mucosa and depletion of lymphocytes in Peyer's patches (Fig. 3). Marked dilatation of ileal crypts with containing inflammatory cells mainly neutrophilic and cellular debris were present. Moderates depletion of lymphocytes was observed in the lymph nodes and spleen of many animals. Lymphohistiocytic infiltrate in the large intestine was also observed.

Macroscopic lung lesions (pneumonia, catarrhal pneumonia) and histopathological lesions (bronchointerstitial and chronic pneumonia, pleuritis, pleuropneumonia) were found in pigs (Fig. 4).

Macroscopically, multifocal to locally extensive reddening of the intestinal mucosa, often located in the colon, were observed in 115 cases. In 9 cases, necrotic enteritis was grossly observed only in the ileum. 


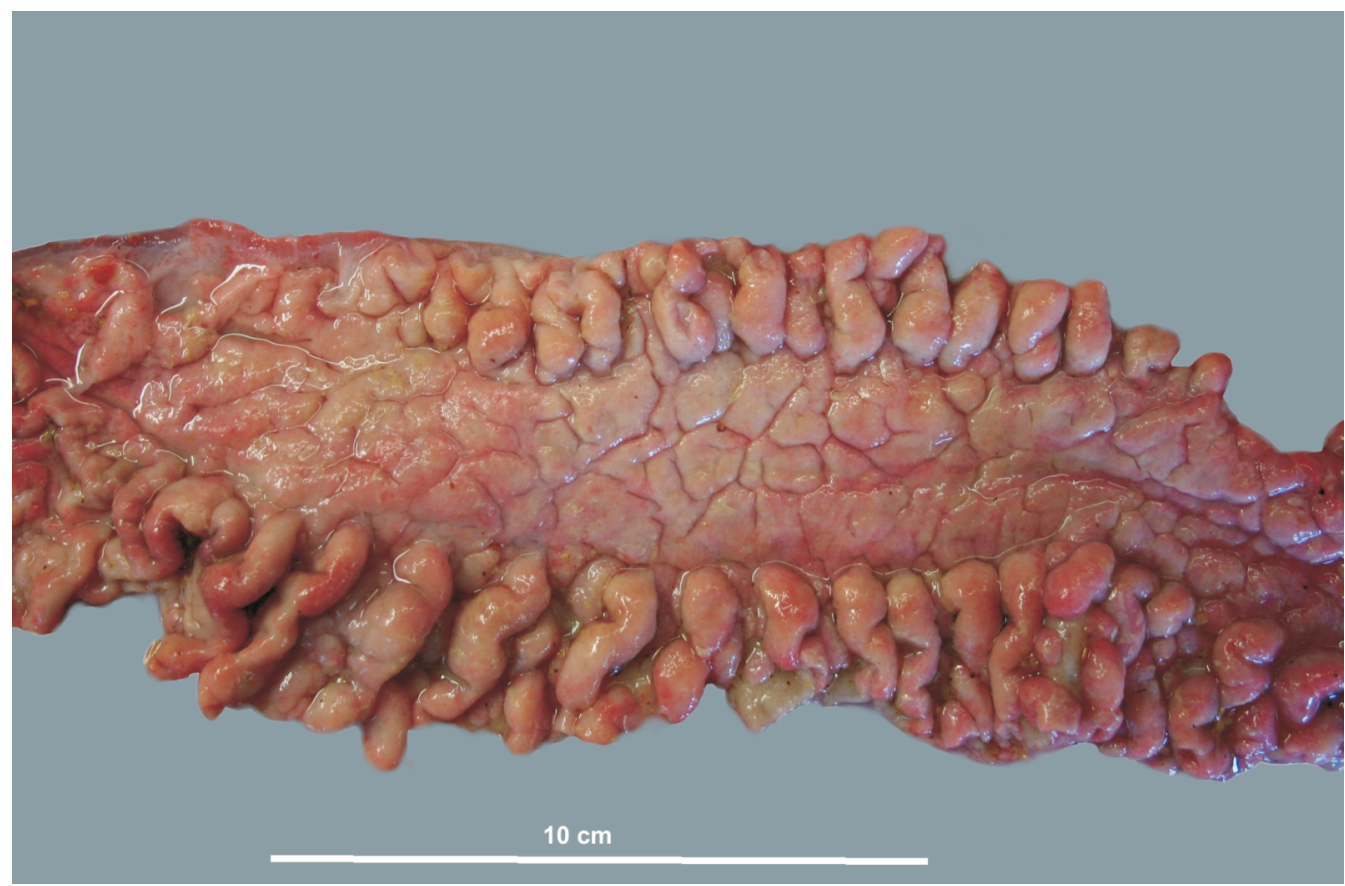

Fig. 2. Ileum from a pig with proliferative enteropathy. Thickening and corrugated appearance of the mucosa.

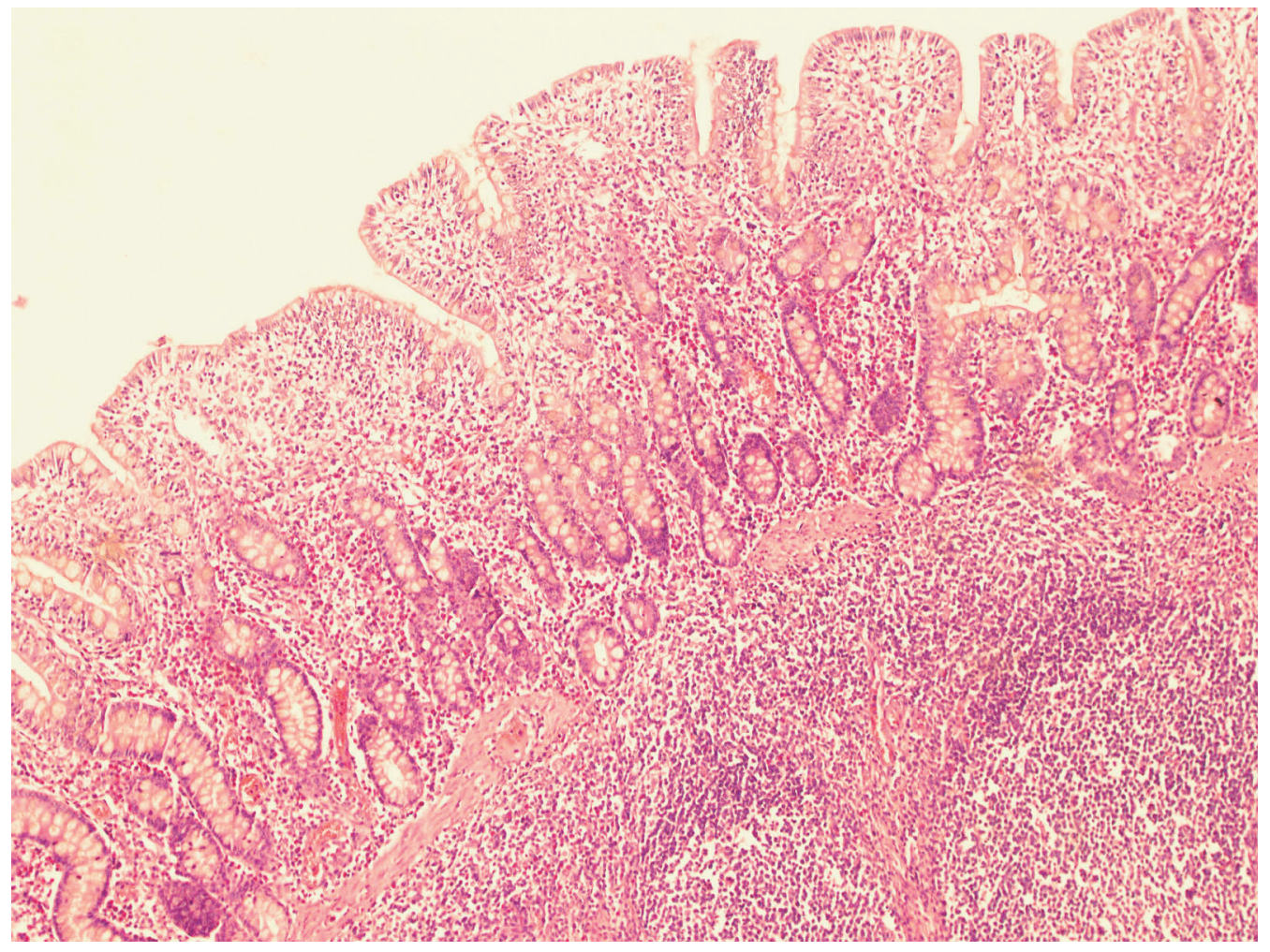

Fig. 3. Ileum of pig with PPE. Thickening of ileum walls. Deformation of the villus. Hyperplasia of lymphoid follicles. HE, x150. 


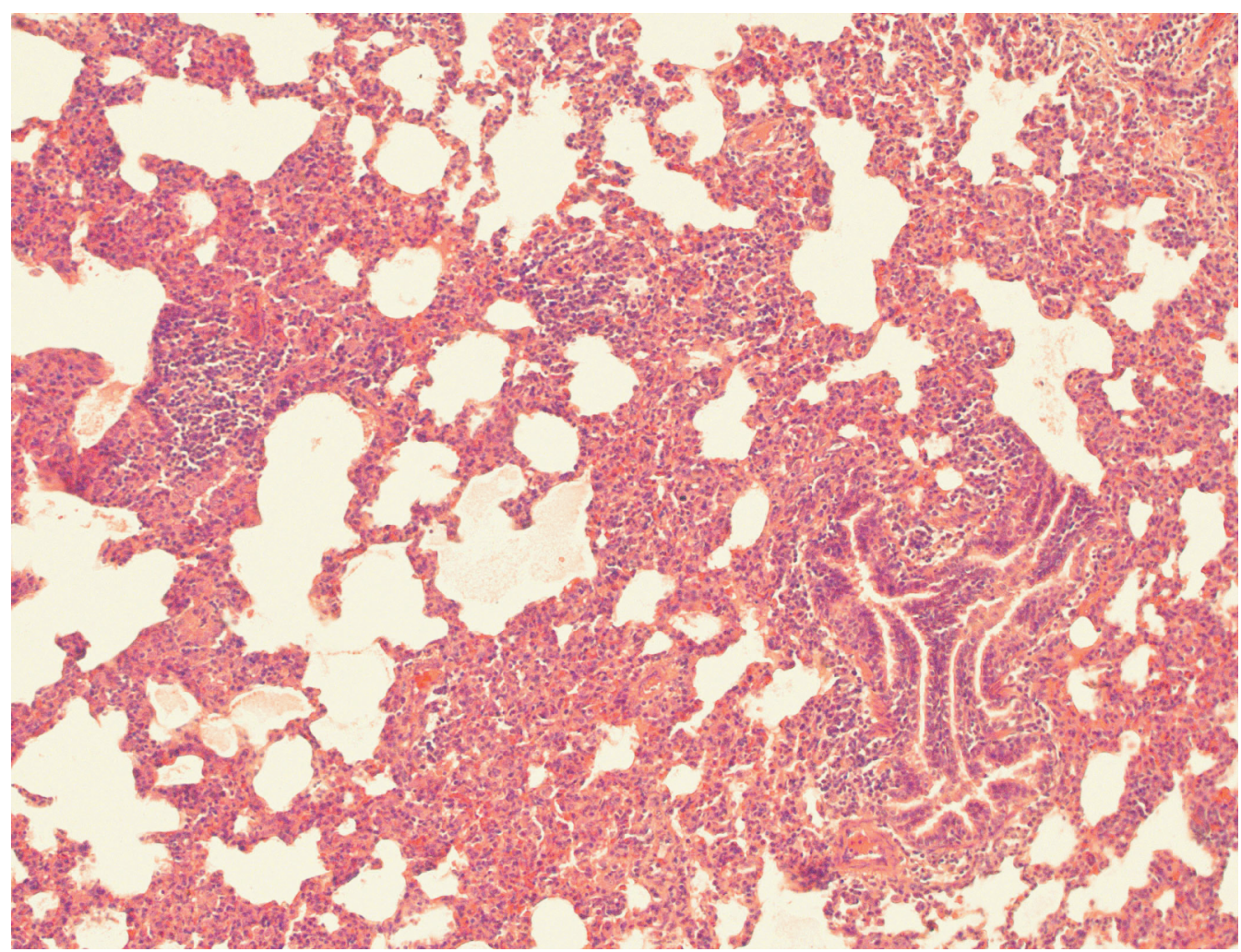

Fig. 4. Lung of pig with PMWS. Subacute interstitial pneumonia. HE, x200.

Table 2. Histopathological changes (\%) in lymphoid nodules and spleen in PCV2 IHC positive pigs.

\begin{tabular}{|c|c|c|c|c|c|c|c|c|c|c|c|c|c|}
\hline & Farm & 1 & 2 & 3 & 4 & 5 & 6 & 7 & 8 & 9 & 10 & 11 & Total \\
\hline \multirow{9}{*}{$\begin{array}{l}\text { Lymphoid } \\
\text { nodules }\end{array}$} & $\begin{array}{c}\text { Number } \\
\text { of specimen }\end{array}$ & 13 & 12 & 7 & 15 & 10 & 9 & 14 & 12 & 8 & 13 & 11 & 124 \\
\hline & $\begin{array}{c}\text { Granulocyte } \\
\text { infiltration }\end{array}$ & $\begin{array}{c}12 \\
(92 \%) \\
\end{array}$ & $\begin{array}{c}12 \\
(100 \%) \\
\end{array}$ & $\begin{array}{c}4 \\
(57 \%) \\
\end{array}$ & $\begin{array}{c}14 \\
(93 \%) \\
\end{array}$ & $\begin{array}{c}9 \\
(90 \%) \\
\end{array}$ & $\begin{array}{c}6 \\
(67 \%) \\
\end{array}$ & $\begin{array}{c}13 \\
(93 \%)\end{array}$ & $\begin{array}{c}11 \\
(92 \%) \\
\end{array}$ & $\begin{array}{c}7 \\
(88 \%) \\
\end{array}$ & $\begin{array}{c}10 \\
(77 \%) \\
\end{array}$ & $\begin{array}{c}9 \\
(82 \%) \\
\end{array}$ & $88 \%$ \\
\hline & $\begin{array}{c}\text { Depletion } \\
\text { of lymphocytes }\end{array}$ & $\begin{array}{c}9 \\
(69 \%)\end{array}$ & $\begin{array}{c}9 \\
(75 \%)\end{array}$ & $\begin{array}{c}2 \\
(29 \%)\end{array}$ & $\begin{array}{c}11 \\
(73 \%)\end{array}$ & $\begin{array}{c}6 \\
(60 \%)\end{array}$ & $\begin{array}{c}2 \\
(22 \%)\end{array}$ & $\begin{array}{c}10 \\
(71 \%)\end{array}$ & $\begin{array}{c}8 \\
(67 \%)\end{array}$ & $\begin{array}{c}5 \\
(63 \%)\end{array}$ & $\begin{array}{c}4 \\
(31 \%) \\
\end{array}$ & $\begin{array}{c}4 \\
(36 \%)\end{array}$ & $59 \%$ \\
\hline & $\begin{array}{c}\text { Presence } \\
\text { of giant cells }\end{array}$ & $\begin{array}{c}3 \\
(23 \%)\end{array}$ & $\begin{array}{c}4 \\
(33 \%)\end{array}$ & 0 & $\begin{array}{c}5 \\
(33 \%)\end{array}$ & $\begin{array}{c}5 \\
(50 \%)\end{array}$ & $\begin{array}{c}3 \\
(33 \%)\end{array}$ & $\begin{array}{c}7 \\
(50 \%)\end{array}$ & $\begin{array}{c}6 \\
(50 \%)\end{array}$ & $\begin{array}{c}2 \\
(25 \%)\end{array}$ & 0 & $\begin{array}{c}1 \\
(9 \%)\end{array}$ & $29 \%$ \\
\hline & $\begin{array}{c}\text { Cytoplasm } \\
\text { inclusions }\end{array}$ & $\begin{array}{c}3 \\
(23 \%)\end{array}$ & $\begin{array}{c}3 \\
(25 \%) \\
\end{array}$ & $\begin{array}{c}1 \\
(14 \%)\end{array}$ & $\begin{array}{c}4 \\
(27 \%) \\
\end{array}$ & $\begin{array}{c}2 \\
(20 \%)\end{array}$ & $\begin{array}{c}1 \\
(11 \%)\end{array}$ & $\begin{array}{c}5 \\
(36 \%) \\
\end{array}$ & $\begin{array}{c}4 \\
(33 \%)\end{array}$ & $\begin{array}{c}3 \\
(38 \%)\end{array}$ & $\begin{array}{c}1 \\
(8 \%)\end{array}$ & $\begin{array}{c}2 \\
(18 \%)\end{array}$ & $24 \%$ \\
\hline & $\begin{array}{l}\text { Histiocyte } \\
\text { infiltration }\end{array}$ & $\begin{array}{c}2 \\
(15 \%) \\
\end{array}$ & $\begin{array}{c}3 \\
(25 \%) \\
\end{array}$ & $\begin{array}{c}1 \\
(14 \%) \\
\end{array}$ & $\begin{array}{c}3 \\
(20 \%) \\
\end{array}$ & $\begin{array}{c}1 \\
(10 \%) \\
\end{array}$ & $\begin{array}{c}1 \\
(11 \%) \\
\end{array}$ & $\begin{array}{c}4 \\
(29 \%) \\
\end{array}$ & $\begin{array}{c}4 \\
(33 \%) \\
\end{array}$ & $\begin{array}{c}1 \\
(13 \%) \\
\end{array}$ & $\begin{array}{c}1 \\
(8 \%) \\
\end{array}$ & $\begin{array}{c}1 \\
(9 \%) \\
\end{array}$ & $18 \%$ \\
\hline & $\begin{array}{c}\text { Parenchymal cell } \\
\text { degeneration }\end{array}$ & $\begin{array}{c}2 \\
(15 \%)\end{array}$ & $\begin{array}{c}5 \\
(42 \%) \\
\end{array}$ & $\begin{array}{c}1 \\
(14 \%)\end{array}$ & $\begin{array}{c}3 \\
(20 \%) \\
\end{array}$ & $\begin{array}{c}2 \\
(20 \%)\end{array}$ & $\begin{array}{c}1 \\
(11 \%)\end{array}$ & $\begin{array}{c}3 \\
(21 \%) \\
\end{array}$ & $\begin{array}{c}3 \\
(25 \%) \\
\end{array}$ & 0 & $\begin{array}{c}1 \\
(8 \%)\end{array}$ & 0 & $18 \%$ \\
\hline & Necrosis & $\begin{array}{c}2 \\
(15 \%)\end{array}$ & $\begin{array}{c}4 \\
(33 \%) \\
\end{array}$ & 0 & $\begin{array}{c}3 \\
(20 \%)\end{array}$ & $\begin{array}{c}1 \\
(10 \%)\end{array}$ & 0 & $\begin{array}{c}2 \\
(14 \%)\end{array}$ & $\begin{array}{c}2 \\
(17 \%)\end{array}$ & 0 & $\begin{array}{c}1 \\
(8 \%)\end{array}$ & 0 & $12 \%$ \\
\hline & $\begin{array}{l}\text { Germinal center } \\
\text { formation }\end{array}$ & 0 & $\begin{array}{c}2 \\
(17 \%)\end{array}$ & 0 & $\begin{array}{c}2 \\
(13 \%)\end{array}$ & 0 & 0 & $\begin{array}{c}2 \\
(14 \%)\end{array}$ & $\begin{array}{c}1 \\
(8 \%)\end{array}$ & 0 & 0 & 0 & $6 \%$ \\
\hline \multirow{2}{*}{ Spleen } & $\begin{array}{c}\text { Granulocyte } \\
\text { infiltration }\end{array}$ & $\begin{array}{c}8 \\
(62 \%) \\
\end{array}$ & $\begin{array}{c}9 \\
(75 \%) \\
\end{array}$ & $\begin{array}{c}2 \\
(29 \%) \\
\end{array}$ & $\begin{array}{c}13 \\
(87 \%) \\
\end{array}$ & $\begin{array}{c}8 \\
(80 \%) \\
\end{array}$ & $\begin{array}{c}5 \\
(56 \%) \\
\end{array}$ & $\begin{array}{c}12 \\
(86 \%) \\
\end{array}$ & $\begin{array}{c}8 \\
(67 \%) \\
\end{array}$ & $\begin{array}{c}6 \\
(75 \%) \\
\end{array}$ & $\begin{array}{c}8 \\
(62 \%) \\
\end{array}$ & $\begin{array}{c}6 \\
(55 \%) \\
\end{array}$ & $69 \%$ \\
\hline & $\begin{array}{c}\text { Parenchymal } \\
\text { cell degeneration }\end{array}$ & 0 & $\begin{array}{c}1 \\
(8 \%)\end{array}$ & 0 & $\begin{array}{c}1 \\
(7 \%)\end{array}$ & $\begin{array}{c}1 \\
(10 \%)\end{array}$ & 0 & $\begin{array}{c}2 \\
(14 \%)\end{array}$ & $\begin{array}{c}1 \\
(8 \%)\end{array}$ & 0 & 0 & 0 & $5 \%$ \\
\hline
\end{tabular}


Microscopically, mucosal necrosis ranged from erosion covered with fibrin exudate to full thickness coagulative necrosis of the mucosa.

Histopathological changes in lymphoid nodules and spleen in PCV2 IHC-positive pigs are summarized in Table 2. Necrotic enteritis was observed in the colon and in the ileum. In severe cases, inflammatory infiltrates were also observed in the submucosa and muscular layer. Giant cells and histiocytic intracytoplasmic inclusion bodies were located predominantly in the Peyer's patches in the small intestine. Epithelial necrosis with crypt dilatation and accumulation of necrotic debris within the crypt lumen occurred in the large intestine and in the small intestine.

\section{Discussion}

The present study describes the presence of $L$. intracellularis and PCV2 in Estonian pig herds using different detection methods.

We have shown that L. intracellularis and PCV2 were more often diagnosed in herds with post-weaning morbidity. E. coli and P. multocida often aggravated the process of illness. Seven herds were infected with both $L$. intracellularis and PCV2. In a Danish investigation $53.1 \%$ pigs with enteritis were infected simultaneously with PCV2 and L. intracellularis (Jensen et al. 2006).

Typically, affected animals exhibiting a chronic course of PPE and wasting syndrome usually experiences diarrhea, respiratory symptoms and reduced weight gain in grower pigs. Opriessnig and Langohr (2012b) declared that disease manifestations associated with PCV2 include postweaning multisystemic wasting syndrome (PMWS), enteric disease, respiratory disease, porcine dermatitis and nephropathy syndrome (PDNS) and reproductive failure.

Porcine circovirus type 2 was first isolated from pigs with PMWS in Canada (Ellis et al. 1998), later in USA, Mexico, Japan, and several European countries (LeCann et al. 1997). In 2006 it was diagnosed first time in Estonia (Timmusk et al. 2008).

Costinar and co-authors (2011) reported that different pathogens can cause diarrhea. They declared that rotavirus, coccidia, E. coli and Balantidium coli were the most important causes of diarrhea in suckling piglets. A prevalence level of $L$. intracellularis infection in Estonian swine herds was higher (63.6\%) compared to Polish swine herds $(33.58 \%$ ) (Pejsak et al. 2007). Pigs were shedding $L$. intracellularis from 5 weeks to 20 weeks of age with a peak of the shedding in pigs aged 11-12 weeks. Similar results are described by many researchers. McOrist and Gebhart
(2006) declared that the PPE occurs mainly in the chronic or sub-clinic form in nursery or grower or finishing pigs between 6-20 weeks of age.

Many investigations claimed that $L$. intracellularis and PCV2 often infected intestine simultaneosly (Jensen et al. 2006, Opriessnig et al. 2012a). Other investigation demonstrated that PCV2 was diagnosed more often in herds infected with other pathogens as PRRSV (Stankevicius et al. 2009, Meng 2013).

L. intracellularis and PCV2 infections have both been associated with diarrhea in weaned pigs and the two infections are grossly indistinguishable. Johansen and co-authors (2013) declared that diarrhea is significant risk factor for low growth rate and that increases in L. intracellularis the odds ratio for a pig to have a low growth rate by two times, but association between PCV2 virus and low growth was not found.

Jensen and co-authors (2006) demonstrated that PCV2 was associated with PPE in commercial swine herds. Co-infection with other pathogens is commonly reported in PMWS affected pigs and it is suggested that a secondary immunodeficiency caused by the virus predisposes these animals to co-infections (Segales et al. 2004). Despite extensive laboratory investigations of PMWS affected pigs, no single viral co-factor has yet been identified as the cause (Lohse et al. 2008). Infection with PCV2 is necessary for the development of PMWS, but most studies has shown that PCV2 needs one or more co-factors for PMWS to develop into severe and even fatal disease (Baekbo et al. 2012). Several pathogens such as porcine parvovirus (Allan et al, 1999) and Mycoplasma hyopneumoniae (Opriessnig et al. 2004) have been shown to enhance the severity of PCV2 infection.

Our results indicated that E. coli was frequent co-factor with PCV2 and L. intracellularis. Pescador (2007) confirmed that E. coli was detected as co-infection with PCV2 in cases positive for mesocolic edema.

The primary reason of post-weaning wasting in swine herds was PCV2 and E. coli (up to 6 weeks old group), and later added (8 weeks and older pigs) $L$. intracellularis and other pathogens.

The characteristic inflammation of PPE mainly occurs in the distal part of the jejunum and in the ileum, but inflammatory changes can also occur in cecum and colon. Similar pathomorphological changes as found in our study are described in several other works (Joens et al. 1997, MacIntyre et al. 2003, Lawson et al. 1993, McOrist et al. 2006). Jensen et al (2006) declared that $L$. intracellularis localised mainly in colon and caused proliferative changes. Our investigations demonstrated that the pathological changes of PPE originates at the beginning of the small intestine. In the ileum there was a reduction or complete absence of goblet cells. The immature enterocytes, on 


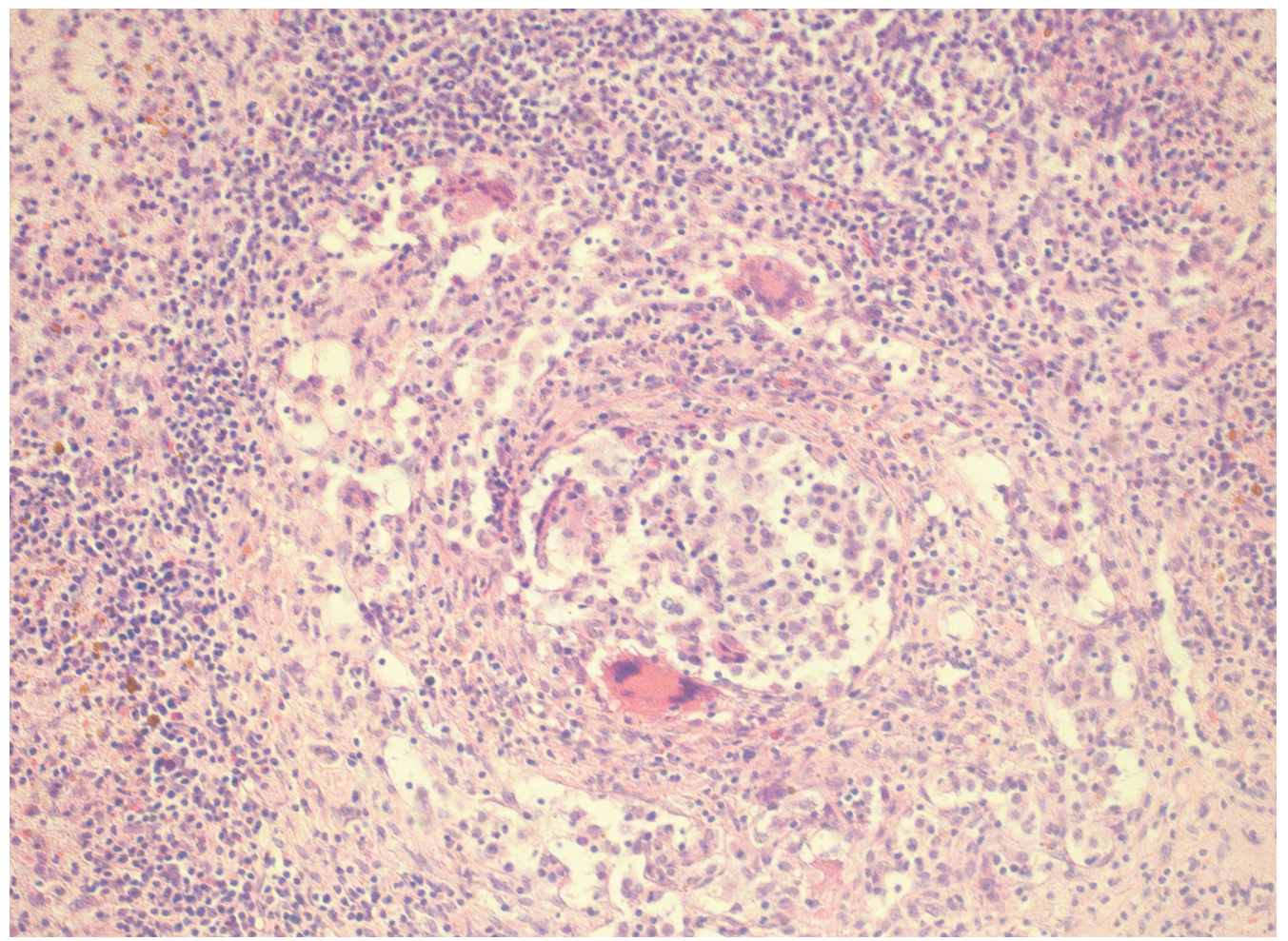

Fig. 5. Mesenterial lymph nodes of pig with PMWS. Presence of giant cells. HE, x300.

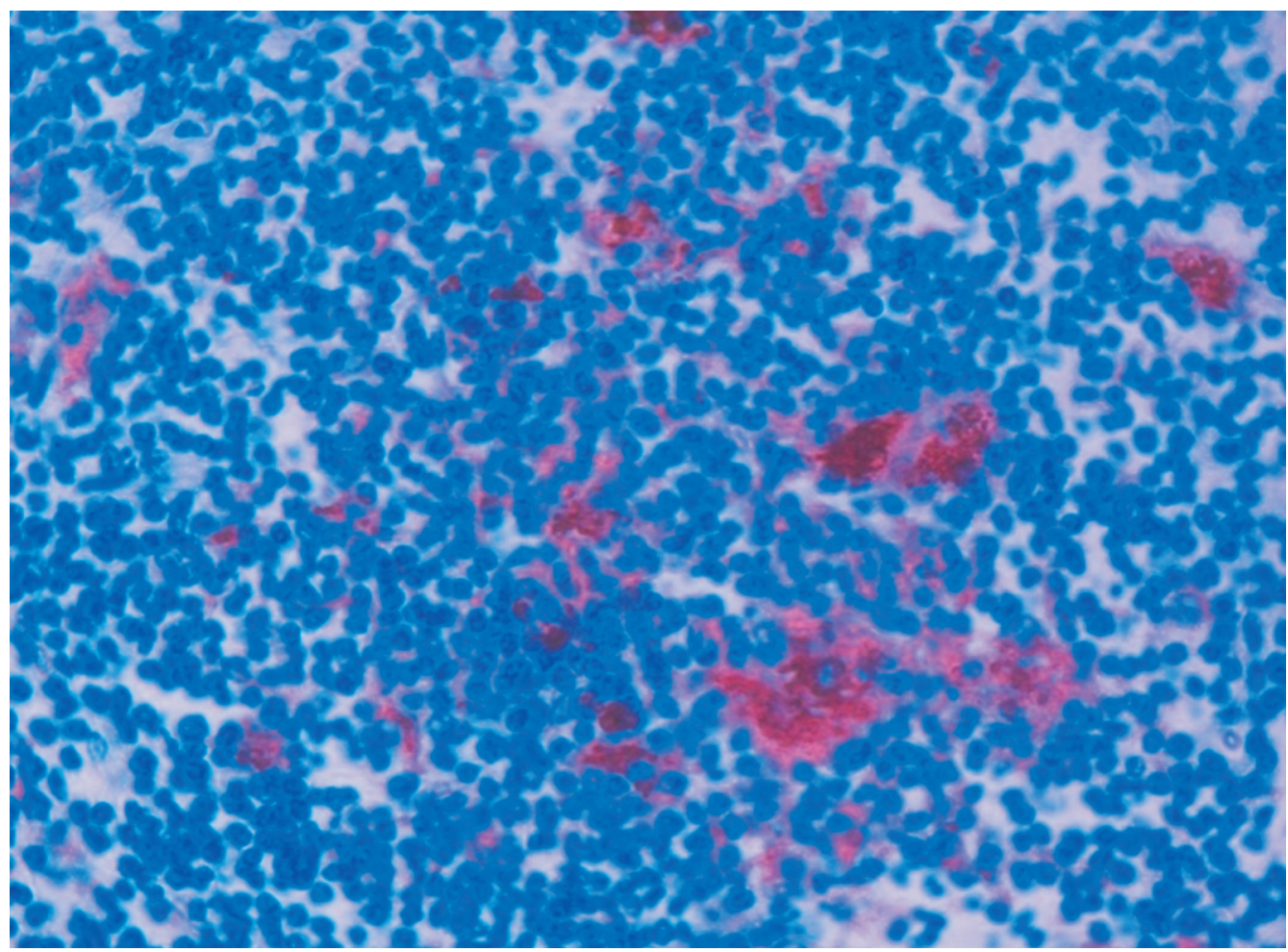

Fig. 6. Mesenterial lymph nodes of pig with PMWS. IHC, x300x 


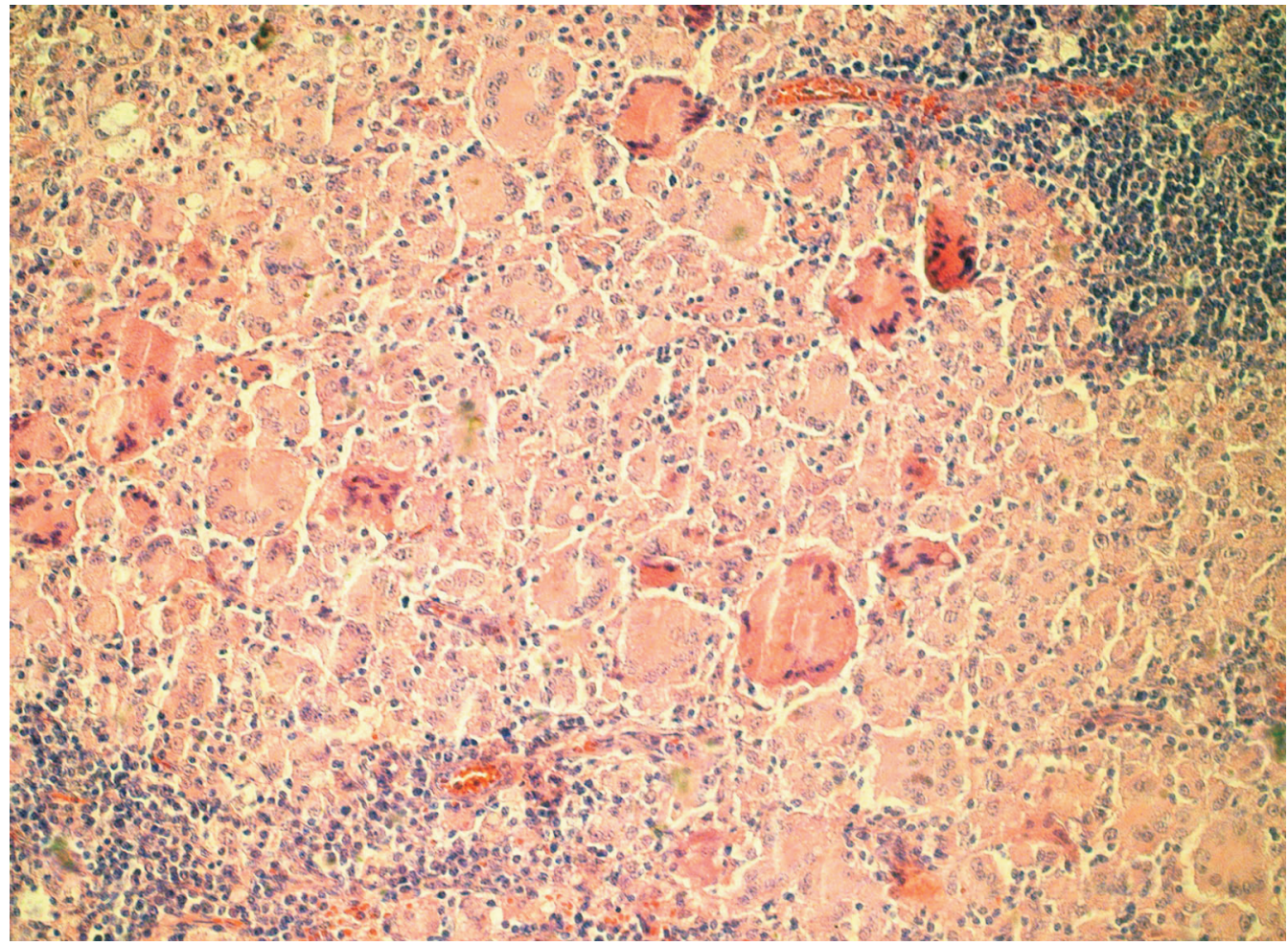

Fig. 7. Mesenterial lymph nodes of pig with PMWS. Presence of giant cells. HE, x400.

the basis of the crypt have a weakly developed microvilli in comparison to the cells located in the apical part. L. intracellularis, E. coli and P. multocida together causes pathological changes both in intestine and lungs. Pigs with PMWS showed different degrees of wasting, generalized lymphadenopathy and lack of lung collapse. The interstitial pneumonia and lymphadenopathy has been detected in PCV2 infection. There was a high grade of pathological changes: proliferative and necrotic pneumonia, lymphoid tissue damage, granulomatous enteritis with infiltration of epithelioid and giant cells in Peyer's patches. Thin walled, fluid-filled intestines have also been described especially in the ileum and proximal colon. Opriessnig and Langohr (2012b) declared that disease manifestations associated with PCV2 include postweaning multisystemic wasting syndrome (PMWS), enteric disease, respiratory disease, porcine dermatitis and nephropathy syndrome (PDNS), and reproductive failure.

Similar pathomorphological changes as found in our study are described in several other works (Mikami et al. 2005, Segales et al. 2005, Martinez et al. 2006, Brunborg et al. 2007, Phaneuf 2007).

In PMWS there were characteristic histological lesions in lymphoid tissues (Table 2). They consist of a variable degree of lymphocyte depletion, together with histiocytic and/or multinucleated giant cell infiltration (Figs. 5 and 7). This basic lymphoid lesion is observable in lymph nodes, Peyer's patches and spleen. In a proportion of cases, basophilic intracytoplasmatic inclusion bodies containing PCV2 materials can be found in cells of the histiocytic lineage (Fig. 6). Sporadically, multifocal coagulative necrosis may be observed. Other histological changes were multifocal lymphohistiocytic interstitial pneumonia, variable degrees of intestinal villous atrophy with variable sloughing and/or regeneration of glandular and cryptal epithelial cells.

Our findings indicated that $L$. intracellularis and PCV2 often infected weaned pigs simultaneously. Associated pathogens in the studied herds may aggrevate the disease and may cause the the pathomorphological changes similar to PPE and PMWS. In infected pigs mostly PCV2 was detected in lymphoid nodes and in spleen.

\section{Acknowledgements}

This work was supported by Estonian Science Foundation grant ETF8914 and by the Estonian Research Council Targeted Financing Project No. SF0140066s09.

\section{References}

Allan GM, Kennedy S, McNeilly F, Foster JC, Ellis JA, Krakowska SJ, Meehan BM, Adair BM (1999) Experi- 
mental reproduction of severe wasting disease by co-infection of pigs with porcine circovirus and porcine parvovirus. J Comp Pathol 121: 1-11.

Baekbo P, Kristensen CS, Larsen LE (2012) Porcine Circovirus Diseases: A reviw of PMWS. Transbound Emerg Dis 59: 60-67.

Brunborg IM, Jonassen CM, Moldal T, Bratberg B, Lium B, Koenen F, Schönheit J (2007) Association of myocarditis with high viral load of porcine circovirus type 2 in several tissues in cases of fetal death and high mortality in piglets. A case study. J Vet Diagn Invest 19: 368-375.

Costinar L, Pascu C, Herman V, Panici G, Balean F, Spiru D, Marecec C, Pava S (2011) Investigation of digestive disorder's etiology in piglets from farms in west of Romania. Lucrari Stiintifice - Universitatea de Stiinte Agricole a Balantului Timisoara, Medicina Veterinara 44: 167-172.

Ellis J, Hassard L, Clark E, Harding J, Allan G, Willson P, Strokappe J, Martin K, McNeilly F, Meehan B, Todd D, Haines D (1998) Isolation of circovirus from lesions of pigs with postweaning multisystemic wasting syndrome. Can Vet J 39: 44-51.

Jacobson M, Englund S, Ballagi-Pordány A (2003) The use of a mimic to detect polymerase chain reaction- inhibitory factors in feces examined for the presence of Lawsonia intracellularis. J Vet Diagn Invest 15: 268-273.

Jacobsen B, Krueger L, Seeliger F, Bruegmann M, Segales J, Baumgartner W (2009) Retrospective study on the occurrence of porcine circovirus 2 infection and associated entities in Northern Germany. Vet Microbiol 138: 27-33.

Jensen TK, Vigre H, Svensmark B, Bille-Hansen V (2006) Distinction between Porcine Circovirus Type 2 Enteritis and Porcine Proliferative Enteropathy caused by Lawsonia intracellularis. J Comp Pathol 135: 176-182.

Joens LA. Nibbelink S, Glock RD (1997) Induction of gross and microscopic lesions of porcine proliferative enteritis by Lawsonia intracellularis. Am J Vet Res 58: 1125-1131.

Johansen M, Nielsen M, Dahl J, Svensmark B, Bćkbo P, Kristensen CS, Hjulsager CK, Jensen TK, Ståhl M, Larsen LE, Angen O (2013) Investigation of the association of growth rate in grower-finishing pigs with the quantification of Lawsonia intracellularis and porcine circovirus type 2. Prev Vet Med 108: 63-72.

Kim J, Chung HK, Chae C (2003) Association of porcine circovirus 2 with porcine respiratory disease complex. Vet J 166: 251-256.

Ladekjćr-Mikkelsen AS, Nielsen J, Stadejek T, Storgaard T, Krakowka S, Ellis J, McNeilly F, Allan G, Botner A (2002) Reproduction of postweaning multisystemic wasting syndrome (PMWS) in immunostimulated and non- immunostimulated 3-week-old piglets experimentally infected with porcine circovirus type 2 (PCV2). Vet Microbiol 89: 97-114.

Lawson GH, McOrist S, Jasni S, Mackie RA (1993) Intracellular bacteria of porcine proliferative enteropathy: cultivation and maintenance in vitro. $\mathrm{J}$ Clin Microbiol 31: 1136-1142.

Lawson GH, Gebhart CJ (2000) Proliferative enteropathy. J Comp Pathol 122: 77-100.

LeCann P, Albina E, Madec F, Cariolet R, Jestin A (1997) Piglet wasting disease. Vet Rec 141: 660.

Lohse L, Botner A, Hansen A S, Frederiksen T, Dupont K, Christensen CS, Baekbo P, Nielsen J (2008) Examination for a viral co-factor in postweaning multisystemic wasting syndrome (PMWS). Vet Microbiol 129: 97-107.
Lomax LG, Glock RD (1982) Naturally occurring porcine proliferative enteritis: pathologic and bacteriologic findings. Am J Vet Res 43: 1608-1614.

MacIntyre N, Smith DG, Shaw DJ, Thomson JR, Rhind SM (2003) Immunopathogenesis of experimentally induced proliferative enteropathy in pigs. Vet Pathol 40: 421-432.

Martínez J, Segalés J, Aduriz G, Atxaerandio R, Jaro P, Ortega J, Peris B, Corpa JM (2006) Pathological and aetiological studies of multifocal interstitial nephritis in wasted pigs at slaughter. Res Vet Sci 81: 92-98.

McOrist S, Gebhart CJ, Boid R, Barns SM (1995) Characterization of Lawsonia intracellularis gen. nov., sp. nov., the obligately intracellular bacterium of porcine proliferative enteropathy. Int J Syst Bacteriol 45: 820-825.

McOrist S, Gebhard CJ (2006) Proliferative enteropathies. In: Straw BE, Zimmerman JJ, D'Allaire S, Taylor DJ (eds) Diseases of Swine. $9^{\text {th }}$ ed., Blackwell, Ames, Iowa, pp 727-737.

Meng XJ (2013) Porcine Circovirus Type 2 (PCV2) Pathogenesis and interaction with the immune system. Annu Rev Anim Biosci 1: 43-64.

Mikami O, Nakajima H, Kawashima K, Yoshii M, Nakajima Y (2005) Nonsuppurative myocarditis caused by porcine circovirus type 2 in a weak-born piglet. J Vet Med Sci 67: 735-738.

Moreno AM, Baccaro MR, Coutinho LL (2002) Lawsonia intracellularis detection in swine feces from important producing regions in Brazil. Arq Inst Biol (San Paulo) 69: 5-8.

Opriessnig T, Thacker EL, Yu S, Fenaux M, Meng XJ, Halbur PG (2004) Experimental reproduction of postweaning multisystemic wasting syndrome in pigs by dual infection with Mycoplasma hyopneumoniae and porcine circovirus type 2. Vet Pathol 41: 624-640.

Opriessnig T, Halbur PG (2012a) Concurrent infections are important for expression of porcine circovirus associated disease. Virus Res 164: 20-32.

Opriessnig T, Langohr I (2012b) Current state of knowledge on porcine circovirus type 2-associated lesions. Vet Pathol 50: 23-38.

Pescador CA, Bandarra PM, Castro L A, Antoniassi NA, Ravazzolo AP, Sonne L, Cruz CE, Driemeier D (2007) Co-infection by porcine circovirus type 2 and porcine parvovirus in aborted fetuses and stillborn piglets in southern Brazil. Pesq Vet Bras 27: 425-429.

Pejsak Z, Zmudzki J, Wasak M, Porowski M, Wojciechowski J, Mirt D (2007) Prevalence of Brachyspira hyodysenteriae and Lawsonia intracellularis infections in Polish swine population. Med Weter 63: 994-996.

Phaneuf LR, Ceccarelli A, Laing JR, Moloo B, Turner PV (2007) Porcine dermatitis and nephropathy syndrome associated with porcine circovirus 2 infection in a Yorkshire pig. J Am Assoc Lab Anim Sci 46: 68-72.

Plawinska J, Klimaczak Z, Jakubowski T, Klawe W, Binek $M(\mathbf{2 0 0 4})$ Nested PCR and IFAT in the diagnosis of porcine proliferative enteritis. Bull Vet Inst Pulawy 48: 247-250.

Quinn PJ, Carter ME, Markey BK, Carter GR (1994) Clinical Veterinary Microbiology. Wolfe Publishing, Mosby, London.

Segales J, Rosell C, Domingo M (2004) Pathological findings associated with naturally aquired porcine circovirus type 2 associated disease. Vet Microbiol 98: 137-149.

Segales J, Allan GM, Domingo M (2005) Porcine circovirus diseases. Anim Health Res Rev 6: 119-142. 
Stankevicius A, Cepulis R, Buitkuviene J, Pockevicius J, Aleksejuniene I, Stankeviciene M, Zilinskas H (2009) Confirmation of Multisystemic Wasting Syndrome (PMWS) in Lithuanian and Latvian Pig Herds Infected with Porcine Respiratory and Reproductive Syndrome Virus (PRRSV). Vet Zoot 45: 60-65.

Stege H, Jensen TK, Møller K, Baekbo P, Jorsal SE (2001) Risk factors for intestinal pathogens in Danish finishing pig herds. Prev Vet Med 50: 153-164.

Suh DK, Song JC (2006) Prevalence of Lawsonia intracellularis, Brachyspira hyodysenteriae and Salmonella in swine herds. J Vet Sci (Korea) 6: 286-293.

Timmusk S, Wallgren P, Brunborg IM, Wikström FH, Allan G, Meehan B, McMenamy M, McNeilly F, Fuxler L,
Belák K, Põdersoo D, Saar T, Berg M, Fossum C (2008) Phylogenetic analysis of porcine circovirus type 2 (PCV2) pre- and post-epizootic postweaning multisystemic wasting syndrome (PMWS). Virus Genes 36: 509-520.

Yeh JY, Kim TJ, Park SY, Song CS, Yoon YD, Kim SK, Lee JB, Choi IS (2006) Isolation of Lawsonia intracellularis in Korea and reproduction of proliferative enteropathy in pigs and hamster. J Vet Med Sci 68: 499-501.

Zhang P, Gebhart CJ, Burden D, Duhamel GE (2000) Improved diagnosis of porcine proliferative enteropathy caused by Lawsonia intracellularis using polymerase chain reaction-enzyme-linked oligosorbent assay (PCR-ELOSA). Mol Cell Probes 14: 101-108. 